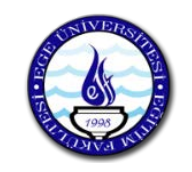

\title{
Erken Çocukluk Eğitimine Küba Perspektifinden Alternatif Bir Bakış: Kendi Çocuğunu
} Eğit Programı

Fatma YALÇIN ${ }^{1}$
Feyza TANTEKIN ERDEN ${ }^{2}$

Geliş Tarihi: 2016-10-11

Kabul Tarihi: 2017-03-23

$\ddot{O} \mathbf{z}$

Küba Devriminden itibaren hayata geçirdiği reformlar sayesinde gelişen dünya ülkeleri arasında en başarılı eğitim sistemlerinden biri olarak görülen Küba Eğitim sistemi, erken çocukluk eğitiminden itibaren ortaya koyduğu yenilikçi uygulamalar ile kendisinden söz ettirmektedir. $\mathrm{Bu}$ yenilikçi uygulamalar arasında yer alan ve Kübalı çocukların yaklaşık \%70'inin faydalandığı Kendi Çocuğunu Eğit programı (Educate Your Child programme) ise ulaştığı kitle ve elde ettiği başarı nedeni ile Küba eğitim sisteminin önemli yapı taşı niteliğindedir. Programın çıkış noktası, geliştirilme ve uygulanma süreci başta olmak üzere sağlık ve eğitim sektörlerini bütünleştiren bir yanının olması, toplumun her kesiminin programın bir parçası olması ve yapılan araştırmalara bağlı olarak sürekli güncellenmesi gibi nedenlerden dolayı bu çalışmada, Kendi Çocuğunu Eğit programının derinlemesine incelenip, gelişmekte olan ülkeler çerçevesinde uygulanabilirliğinin tartışılması amaçlanmıştır. Bu amaç doğrultusunda ilgili alanyazın ve UNICEF ve UNESCO gibi uluslararası kuruluşların raporları incelenerek önemli noktalar vurgulanmıştır. İlgili alanyazının incelenmesi ve irdelenmesi doğrultusunda, bu programın gelişmekte olan ülkeler için örnek alınması gereken pek çok yönünün olduğu düşünülmektedir.

Anahtar Kelimeler: Küba Gelişim Modeli, Küba eğitim sistemi, Küba erken çocukluk eğitimi, kendi çocuğunu eğit programı, alternatif erken çocukluk eğitim modeli

\footnotetext{
${ }^{1}$ Araş. Gör., ODTÜ Eğitim Fakültesi, Okul Önc. Eğit. A.B. D., fatma.ay.17@gmail.com

${ }^{2}$ Doç. Dr., ODTÜ Eğitim Fakültesi, Okul Önc. Eğit. A.B. D, tfeyza@metu.edu.tr
} 


\title{
An Alternative Method in Early Childhood Education from Cuban Perspective: Educate Your Child Programme
}

\begin{abstract}
The Cuban education system, which is considered as one of the most successful educational systems among the developing countries due to the reforms since the Cuban Revolution, comes into prominence with innovative practices that have emerged in early childhood education. Educate Your Child Programme, which is one of those innovative practices and is utilized by $70 \%$ of Cuban children, constituted a significant part of Cuban Education System owing to its successful outcomes in early childhood education. Due to the fact that Educate Your Child programme includes the integration of health and education, participation by all sectors of society, early intervention and prevention, and on-going development mentoring, this study aims to examine this programme in detail and to discuss the applicability of it in developing countries. To this end, related literature and reports by UNICEF and UNESCO about Cuban early childhood education are examined in detail. Depending on related literature, this study suggests that Educate Your Child programme may be an alternative early childhood educational model for developing countries.
\end{abstract}

Keywords: Development Model of Cuba, Cuban education system, Cuban early childhood education, educate your child programme, alternative early childhood education model 
“Dünya'nın en mutlu ülkesi, düşünce ve duyguları eğitilmiş bireylere sahip olan ülkedir... Ĕgitimin ruhu öğretmendir... Hiç kimse Kübalı öğretmenden daha fazla adanmış değildir. Aramızdan kim okuma-yazmayı küçük devlet okullarında öğrenmemiştir ki? Şimdi zaman çocuklarımızı eğitmek gibi kutsal bir görevi emanet ettiğimiz bu genç kadın ve erkeklere çok az ücret ödemeyi bırakma zamanıdır" (Castro, 2004, s.313)

\section{Giriş}

Erken çocukluk dönemi 0-8 yaşı kapsayan, beyin gelişimi başta olmak üzere (Fisher, 2011; Haartsen, Jones ve Johnson; 2016; Nagel, 2012) diğer gelişim alanlarında (fiziksel, dil ve sosyal duygusal gelişim), yaşamın sonraki yıllarına kıyasla çok hızlı ilerlemenin görüldüğü bir dönem olarak ifade edilmektedir (Center on the Developing Child, 2010; National Association for the Education of Young Children[NAEYC], 2000). Bu dönemin, büyüme ve gelişimin çok hızlı olması nedeniyle kritik bir öneme sahip olduğu sıklıkla vurgulanmaktadır (Güven ve Efe-Azkesin, 2014). Bu dönemin öneminin bir diğer nedeni ise erken çocukluk döneminde erken teşhis ve tanı yoluyla muhtemel pek çok risk faktörünün ve gelişimsel problemlerin önüne geçilebilmesidir (Center on the Developing Child, 2010; NAEYC, 2000; United Nations International Children's Emergency Fund [UNICEF], 2016). Diğer bir deyişle, erken çocukluk dönemi yaşamın ileriki yıllarının temellerinin atıldığı özel bir dönemdir. Dolayısıyla erken çocukluk döneminde çocuğa sağlanacak sağlıklı beslenme ile birlikte nesne ve bireylerle etkileşimin sağlandığı pozitif bir çevrenin önemi giderek artmaktadır. Bu öneme bağlı olarak, çocuğun yaşamın ilk yıllarından itibaren uygun gelişimsel uyaranlar içeren destekleyici bir ortamda eğitilmesi gündeme gelmiştir. Yaşamın ilk yıllarından itibaren çocuğa sağlanan ve erken çocukluk eğitimi olarak tanımlanan eğitimin amacı ise çocuğun ileriki yılları için bir temel oluşturmaktır. Nitekim, Yoshikawa ve diğerleri (2013) tarafından yürütülen bir çalışmada, nitelikli okul öncesi eğitim alan çocukların gelişimsel alanlara ilişkin becerilerinin daha iyi olduğu ve sonraki eğitim düzeylerinde akademik başarılarının daha yüksek olduğu ortaya koyulmuştur. Benzer bir şekilde erken çocukluk eğitimi alıp almama durumu ile PISA ve TIMMS gibi uluslararası sınavlarda öğrencilerin elde ettiği başarı arasındaki ilişkiye odaklanan çalışmalar da (Organization for Economic Cooperation and Development [OECD], 2010; OECD, 2012), bu çalışmanın sonuçlarını destekler niteliktedir.

İleri sürülen bu nedenlerden dolayı erken çocukluk eğitiminin önemi tüm dünyada hızla artmıştır. Ancak küresel seviyede böyle bir artış söz konusu olsa da, farklı ülkeler özelinde bu önemin ne durumda olduğu ve ne gibi uygulamaların yapıldığg ilgi uyandıran bir 
konudur. Örneğin, günümüzde Montessori, Reggio Emilia, Waldorf, Bank Street başta olmak üzere pek çok alternatif erken çocukluk eğitim yöntemi ve yaklaşımları yaygınlaşarak farklı ülkelerde uygulanmaya başlanmıştır. Fakat ne var ki ismi bahsedilen veya bahsedilmeyen bu yöntem ve yaklaşımların çoğu, yaygınlaştığı ülkelerde özel eğitim kurumları tarafından uyarlanarak hayata geçirildiği için gelir düzeyi yüksek ailelerin çocuklarının erişebildiği birer eğitim yaklaşımı haline gelmişlerdir (Warddle, 2009). Öte yandan, özellikle gelişmekte olan dünya ülkeleri için her sosyo-ekonomik düzeyden çocuğa hitap eden, kapsayıcılığı yüksek, nitelikli okul öncesi eğitimi sağlamak hala tam anlamıyla gerçekleştirilememiştir (OECD, 2015). Bu çerçeveden bakıldığında, farklı ülkelerde uygulanan iyi örnekleri ortaya koymak ve bu örnekleri her yönüyle tartışmak, gelişmekte olan ülkelere örnek oluşturabilir ve bu ülkeler elde ettikleri veriler ışığında kendi uygulamaları için kültürel uyarlamalar yapabilirler. Bu kapsamda özellikle, ekonomik problemlerle baş etmenin yanı sıra eğitimde niteliği ve niceliği arttırmayı başarabilen ülkelerde ortaya çıkan iyi uygulamaların daha da önem arz ettiği düşünülmektedir.

$\mathrm{Bu}$ nedenle bu çalışma, Küba erken çocukluk dönemi eğitim modelini ve bu modelin ürünü olan Kendi Çocuğunu Eğit programını (Educa a Tu Hijo- Educate Your Child) derinlemesine inceleyip, gelişmekte olan ülkeler çerçevesinde uygulanabilirliğini tartışmayı amaçlamıştır. $\mathrm{Bu}$ amaç doğrultusunda ilgili alanyazın incelenmiş ve önemli noktalar vurgulanmaya çalışılmıştır. Ancak Küba erken çocukluk eğitim sistemini ve Kendi Çocuğunu Eğit programını anlamak ve alana getirdiği yenilikleri izleyebilmek için bir ülke olarak Küba'yı ve dünyada beğeni ve kabul gören Küba gelişim modelinin özelliklerini sunmanın gerekli olduğu düşünülmektedir. Bu amaçla bu çalışmada ülke olarak Küba ve onun gelişim modeline özetle değinilmiştir.

\section{Küba Gelişim Modeli ve Eğitime Yansımaları}

Florida'nın güneyinde, Karayip Denizi ve Kuzey Atlantik Okyanusu arasında yer alan bir ada olan Küba, bir Latin Amerika ülkesidir. Başkenti Havana olan ve nüfus açısından bölgedeki en büyük ülke olan Küba’nın nüfusu 11.363.000'dir. Bu nüfusun sadece \%23'ü kırsal kesimde yaşamaktadır (United Nations Educational, Scientific and Cultural OrganizationUNESCO, 2013). Son zamanlara kadar, dünya basınında önyargı ve belirli kalıp yargılarla yansıtılmaya çalışılsa da (McCKloskey, 2011) Küba, kendine has kültürü, sosyal yapısı ve yönetim şekli ile alışageldiğimizin dışında bir ülkedir. Resmi adı Küba Cumhuriyeti olan ülke komünizm ile yönetilmektedir. Küba 1961’den beri Amerika Birleşik Devletleri ambargosuna 
maruz bırakılmış ve bu süre boyunca Sovyet Sosyalist Cumhuriyetler Birliği’nin desteği ile ekonomisini güçlü tutmaya çalışmıştır. Ancak birliğin yıkılmasından dolayı yardım kesilmiş ve Küba’da ekonomiyi derinden sarsan bir ekonomik kriz yaşanmıştır. Yaşanan bu kriz Küba'yı ekonomide liberalleşmeye yöneltmiş ve bugünkü anlamda Küba'nın güçlenmesine neden olan gelişim modelinin temelleri atılmıştır (British Broadcasting Corporation[BBC], 2014). Yaşadığı ekonomik problemler nedeniyle sahip olduğu kaynakları asgari düzeyde kullanma yoluna giden Küba yönetimi, sağlık ve eğitim sektöründe önleyici hizmetlere odaklanmıştır. Bu çerçevede gerçekleştirilen sosyal politikalar doğrultusunda, 1960 yılında Ulusal Sağlık Sistemi kurulmuş, 1961 yılında Ulusal Okuma Yazma Kampanyası başlatılmış, 1976 yılında toplum poliklinikleri kurulmuş, 1980 yılında Erken Eğitim Sistemi kurulmuş, 1984 yılında aile doktoru kavramı toplumla tanıştırılmış ve 1992 yılında Kendi Çocuğunu Eğit programı başlatılmıştır (Tinajero, 2010). Birbiri ile bütünleşik bir şekilde gerçekleştirilen bu reformlar sayesinde Küba halkı, hem yaşadığg ekonomik krizin zorluklarına dayanmış, hem de eğitim ve sağlık başta olmak üzere pek çok alanda gelişmiştir (McCloskey, 2011).

Toplumun geçirdiği bu değişim ve gelişim sürecindeki en büyük katkıyı, pek çok uluslararası kuruluş ve UNICEF tarafından takdir edilen okuma yazma kampanyasının yaptığı düşünülmektedir. Bu kampanya sürecinde, Batista döneminde ihmal edilmiş halka okumayazma öğretilmiş ve okuma-yazma oranı \%100’e çıkarılmıştır. Elde ettiği bu başarıyla oldukça ün kazanan bu okuma-yazma programı diğer 12 Latin Amerika ülkesinde de uygulanmaya başlanmıştır (McCloskey, 2011; UNICEF, 2013). Küba, eğitime verdiği önem, eğitime ayırdığg bütçeyle de kendinden söz ettirmektedir. Birleşmiş Milletlerin (United Nations) 2015 İnsani Gelişim Raporuna (Human Development Report) göre, Küba'nın 20052014 yılları arasında eğitime ayırdığı bütçe gayri safi milli hasılanın \% 12,8’ini teşkil etmektedir ki, bu oran OECD tarafindan hazırlanan raporlarda belirtilen verilerle kıyaslandığında, Türkiye’nin gayri safi milli hasıladan eğitime ayırdığı \%4,4’lük bütçeden ve hatta Yeni Zelanda'nın gayri safi milli hasılasının \% 6,9'unu teşkil eden eğitim bütçesinden (OECD ortalaması \% 5,3) bile daha yüksektir (OECD, 2015). Elbette ki bu oranların parasal karşılıkları Yeni Zelanda gibi ekonomik olarak gelişmiş olan ülkelerin harcadıkları paralardan rakamsal olarak daha küçük olabilir. Ancak burada dikkati çeken husus, pek çok ekonomik sıkıntıyla mücadele etmek durumunda kalan bir hükümetin, kısa vadede küçük çapta gelişimler sağlayacak ekonomik yatırımlar kaygısı gütmeden, daha uzun vadede sonuçlar doğuracak ve halkın refahını temelden etkileyecek etkili çözümler için kararlılıkla mücadele edebilme çabasıdır. 
Küba'nın gelişim modelinde en az eğitim kadar önem teşkil eden bir başka husus ise sağlık sektörüdür. Nitekim eğitimde olduğu gibi sağlık sektörüne ayrılan ekonomik bütçe de gayri safi milli hasılanın önemli bir kısmını oluşturmaktadır. Birleşmiş Milletler 2015 İnsani Gelişim Raporuna göre 2013 yılı itibariyle Küba'nın sağlık harcamaları, gayri safi milli hasılasının \%8,8'ini oluşturmaktadır ki bu oran, raporda belirtilen \%9,9'luk dünya ortalamasına ve \%12,3'lük OECD ortalamasına oldukça yakın ve Türkiye'nin milli hasıladan sağlık harcamalarına ayırdığı \%5,6’lık bütçeden daha yüksek bir orandır. Ayrılan bu bütçeden yararlanılarak, eğitimde olduğu gibi sağlık hizmetleri de Küba'da herkese ücretsiz olarak sunulmaktadır. Ancak, sağlık hizmetlerinin ücretsiz sunulmasından öte, bu hizmetin Küba halkı için önleyici ve destekleyici bir sistem olması nedeniyle daha da önem arz etmektedir. Zira bu sistem sayesinde sadece hastalıkların önlenmesi değil aynı zamanda sağlıklı bir yaşam tarzının da halk tarafından benimsenmesi hedeflenmiştir (McCloskey, 2011). Bu çabaların sonucunda Küba'da umulan yaşam süresi 79'a yükselmiş, bebek ölüm oranı her 1000 doğumda 5,3'e düşürülmüştür. Bu göstergelerin Dünya ve Türkiye açısından ne ifade ettiği değerlendirildiğinde, dünyada bebek ölüm oranının 36. 6, OECD ülkelerinin ortalamasının 6,5 ve Türkiye'de ise 16,5 olduğu görülmektedir. Benzer bir şekilde, Türkiye'de umulan yaşam süresi 75,3, dünya ortalaması 71,5 ve OECD ortalaması ise 80,2'dir ki bu oranlar Küba'nın sağlık ve sağlıklı yaşam hususunda kaydettiği ilerlemelerin uluslararası kanıtları niteliğindedir (Birleşmiş Milletler[BM], 2015; UNESCO, 2013).

Küba'nın sağlık ve eğitim sektörlerinde gösterdiği bu ilerlemeler Küba'yı Birleşmiş Milletler İnsani Gelişim Raporunda yapılan sıralamada yüksek insani gelişim gösteren ülkeler arasına taşımıştır (BM, 2015). Çünkü sağlık ve eğitim alanlarında gerçekleştirilen iyileştirme ve ilerlemeler, bir ülkeyi gelişmiş kabul etmedeki en önemli göstergeler arasındadır (Dünya Bankası, 2014). Bir sonraki bölümde Küba'da var olan eğitim anlayışı ve bu eğitim anlayışı çerçevesinde şekillenen eğitim sistemine yer verilmiştir.

\section{Küba’da Eğitim Anlayışı}

Küba Eğitim sistemi, Küba devriminden beri Dünya Bankası ve Uluslararası Para Fonu (IMF) gibi kuruluşlardan tek bir kuruş dahi almaksızın, gelişen dünya ülkeleri arasında en iyi eğitim sistemlerinden biri olarak kendisinden söz ettirmektedir (Beridlid, 2007; Gasperini, 2000; Mandrapa, 2015). Bu nedenle doğudan batıya kuzeyden güneye pek çok dünya ülkesi için derinlemesine irdelenmesi gereken alternatif bir eğitim modeli niteliğindedir (Beridlid, 2007). Diğer taraftan, hiçbir uluslararası kuruluştan maddi destek alınmamasına rağmen Küba’da 
eğitim, sadece parasını ödeyebilenlerin ulaşabileceği bir olgu olmaktan çıkarılarak, toplumun her kesimine ulaştırılması gereken bir insan hakkı olarak görülmektedir (McCloskey, 2011). $\mathrm{Bu}$ çerçeveden bakıldığında Küba eğitim sistemini en iyi şekilde tanımlayabilecek kelime öbeğinin Herkes İçin Eğitim olduğu düşünülmektedir. Zira Küba'da eğitim, tüm kademeleri boyunca ücretsiz olarak toplumun tüm kesimlerine sağlanmaktadır. Yerel farkl1lıklar göz önünde bulundurularak herkese aynı eğitim programı uygulanmaktadır. Ayrıca, eşitlik ve adalet olgusunu topluma hissettirebilmek adına özel eğitime ihtiyaç duyan bireylerin normal eğitim sistemi içerisinde yer alabilmeleri için gerekli düzenlemeler yapılmaktadır. Bunların yanı sıra resmi eğitim sistemi içerisinde yer alamamış bireyler için yetişkin eğitimleri sunulmaktadır (Gasperini, 2000). Bu uygulamaların, "Herkes İçin Eğitim” olgusunun en önemli göstergelerinden olduğu düşünülmektedir. "Herkes için Eğitim” olgusuna delil oluşturacak bir başka husus ise çocuk gelişim hizmetlerinin ve sağlıklı çocuk gelişimine yönelik göstergelerin şehir merkezi ve kırsal kesimlerde önemli ölçüde bir farklllık göstermemesidir. Çünkü devlet tarafından her çocuğa firsat eşitliği yaratan, kamu yararını gözeten politika ve programlar üretilerek her çocuğun sahip olduğu potansiyel gelişimin en üst düzeyine çıkabilmesi hedeflenmektedir (Tinajero, 2010; UNICEF, 2016). Devletin ürettiği bu politikalara ilişkin UNICEF Küba temsilcisi José Juan Ortiz’in bir röportajda söylediği sözler oldukça çarpıcıdır. José Juan Ortiz;

“Küba, bir ülkenin çocuklarının haklarını korumak için zengin olmasının şart olmadĭ̆ını göstermiştir. Çocuk haklarl sözleşmesi 20 ylldır yürürlükte ve biz hala sokakta yaşayan, okula gitmeyen, tarım işinde veya seks işçisi olarak çalıştırllan yüz milyonlarca çocuğu konuşuyoruz. Ancak bu çocukların hiçbiri Kübalı değil çünkü hak temelli ve koruyucu politikalar geliştiren bir hükümet var” demiştir (Gorry, 2010 s.12).

Küba eğitim anlayışını bir anlamda özetleyen bu alıntının da işaret ettiği üzere Küba, koruyucu ve hak temelli politikalarını erken çocukluk eğitiminden başlamak üzere eğitimin her kademesine yansıtmaya çalışmıştır (Miller, 2002; UNICEF, 2016).

\section{Küba Eğitim Sistemine Genel Bir Bakış}

Küba'da okul öncesi eğitimden başlamak üzere eğitimsel politikaları yönetmek ve düzenlemekten Eğitim Bakanlığı sorumludur (Tinajero, 2010). Küba Eğitim Bakanlığı 2012 yılında yeni bir eğitimsel dönüşüm programı başlatmıştır. Bu program çerçevesinde niteliği arttırmak amacıyla özellikle zorunlu eğitim düzeyini etkileyecek bazı reformlara gidilmiştir. Her sınıfa bir televizyon sağlanması, bilgisayar okur-yazarlığının arttırılması, ilköğretim 
kademesinde her sınıfta en fazla 20 öğrencinin, ortaöğretim kademesinde her sinıfta en fazla 15 öğrencinin eğitim alması gibi değişimler bu yeni eğitim reformunun birer parçası olmuşlardır (Breidlid, 2007).

Küba'nın eğitimsel reformlarına paralel olarak devam eden eğitim sistemi genel olarak irdelendiğinde oldukça kapsayıcı bir yapıya sahip olduğu görülür. Zorunlu eğitim altı yaştan başlayarak dokuz yıl sürmektedir ve temel ortaöğretim eğitimi sonunda tamamlanmaktadır. Küba'da, zorunlu eğitim kapsamında olmayan okul öncesi eğitim 6 ay-5 yaş aralığını, ortaöğretim sonrası eğitim 15-17 yaş aralığını ve yükseköğrenim ise 18-22 yaş aralığını kapsamaktadır. Zorunlu eğitim yıllarını kapsayan temel eğitim ve temel ortaöğretim düzeyinde akademik yıl, eylül ayında başlar temmuz ayında ise sona ermektedir (López, 2011; UNESCO, 2013).

Küba'da zorunlu eğitim süresince standart bir program uygulanmaktadır. İlköğretim düzeyindeki öğrenciler matematik, İspanyolca, coğrafya ve doğa bilimleri gibi derslerin yanında değerler eğitimi ve iş eğitimi gibi dersler almaktadır. Değerler eğitimi derslerinin amacı Küba'ya ait değerler ve gelenekleri kazandırmanın yanı sıra etik ve ahlak kurallarını da çocuklara kazandırmaktır. İş eğitimi dersi ise okul ortamında iş ve çalışmayı bütünleştirmeyi hedeflemektedir. İş eğitimi dersinde çalışma ve emeğin değerinin öğrenciler tarafindan anlaşılmasını sağlamak amacıyla öğrencilerin okul bahçesinde şeker gibi bazı tarımsal ürünleri yetiştirmesi beklenmektedir. Ortaöğretim düzeyinde ise temel derslerin yanı sıra yine iş eğitimi, değerler eğitimi ve Marksizm ve Leninizm'in temelleri gibi dersler yer almaktadır (Gasperini, 2000).

Zorunlu eğitim sürecini tamamlayan öğrenciler için iki farklı seçenek sunulmaktadır. $\mathrm{Bu}$ öğrenciler mesleki ve teknik eğitim alarak hizmet sektöründe istihdam edilme şansına sahip olabilir veya yükseköğretim düzeyinde eğitim alarak farklı bir alanda çalışabilirler. Küba ekonomisinin \%73,9'una temel oluşturan hizmet sektöründe yer almayı tercih eden öğrencilerin mesleki ve teknik eğitim veren okullara devam etmeleri gerekmektedir (Gasperini, 2000). Yükseköğretim düzeyinde eğitim almak isteyen öğrenciler için ise lisans (4-5 yıl), yüksek lisans (ortalama 2 yıl veya üzeri) ve doktora (ortalama 4 yıl veya üzeri) olmak üzere üç aşama şeklinde eğitim alma şansı söz konusudur (Wolf, Penton, Marin, ve Romero, 2011). Yüksek öğretim düzeyinde eğitim alan öğrencilerin \%34'ü öğretmen eğitim programlarını, \%19,2'si sosyal ve beşeri bilimleri ve \%15.4'ü ise tıbbi bilimleri tercih etmektedir. Bu oranlar değerlendirildiğinde son 30 yılda Küba'da her şehir başına düşen 
öğretmen ve doktor sayısında bir artış olduğu açıklanmıştır (Tinajero, 2010). Küba’da yükseköğretime kayıt düzeyi ise \%45'tir ve bu oran diğer Latin Amerika ülkeleri ile kıyaslandığında Küba’nın yükseköğretime kayıt düzeyi en yüksek Latin Amerika ülkesi olduğu görülmektedir (Fry, 2002).

Küba'da genel eğitimin yanı sıra özel eğitime de oldukça önem verildiği ifade edilmektedir. Bu doğrultuda herkes için eğitim olgusunu temel alan bir yapıya sahip olan Küba Eğitim sisteminde eğitimin her kademesinde özel eğitime ihtiyaç duyan bireylere eğitim verilmeye çalışılmaktadır. Bu bireylerin eğitimi gerek özel eğitim kurumlarında gerekse normal eğitim kurumlarında kaynaştırma eğitimi yapılarak sürdürülmektedir (Barredo, 2013; Gasperini, 2000;).

$\mathrm{Bu}$ çalışmada Küba eğitim anlayışı ve eğitim sistemi genel çerçevede sunulduktan sonra, bu bölümden itibaren Küba eğitim sisteminin temel yapı taşlarından biri haline gelen Küba erken çocukluk eğitimi ve bu eğitimin en kapsayıcı programı haline gelen Kendi Çocuğunu Eğit Programı tanıtılmıştır. Kendi Çocuğunu Eğit Programı, çıkış noktası ve gelişimsel süreci, değerlendirme yöntemlerine değinilerek sunulmuştur.

\section{Küba Erken Çocukluk Eğitimi}

Küba'da doğum öncesi süreçten başlamak kaydıyla çocuğa sadece eğitim sağlamayan, aynı zamanda yeterli beslenme ve sağlık hizmetleri de sunan bütünsel bir erken çocukluk gelişimi eğitimi benimsenmiştir. Devletin ürettiği, koruyucu ve hak temelli politikaların başında erken çocukluk eğitimine ilişkin yürütülen çalışmalar bulunmaktadır (Miller, 2002; UNICEF, 2016).

Küba erken çocukluk eğitimi Küba tarihine paralel olarak iki farklı döneme ayrılmaktadır. Bunlardan birincisi Küba devriminden önceki dönemdir ki bu dönemde sağlık hizmetlerinin oldukça yetersiz olduğu belirtilmektedir. Bu dönemde ülke genelinde sadece 300 tane çocuk sağlık merkezinin bulunduğu ve çocuk ölüm oranının ise her 1000 çocukta 54 olduğu saptanmıştır. İkinci döneme yani devrimden sonraki döneme gelindiğinde ise sağlık ve eğitim sektöründe birçok gelişim ve ilerlemelerin olduğu kaydedilmiştir. Bu durumun doğal bir sonucu olarak çocuk ölüm oranı ve düşük doğum ağırlıklı çocuk oranında gelişmiş ülkelerle kıyaslanacak düzeyde bir düşüş yaşandığı saptanmıştır (Tinajero, 2010; UNESCO, 2006).

Günümüz itibariyle ise Küba’da 0-6 yaş arası yaklaşık olarak 855.000 çocuk yaşamaktadır ve erken çocukluk eğitimi zorunlu olmamasına rağmen bu çocukların \%99’u 
ücretsiz olarak kurumsal veya kurumsal olmayan bir erken çocukluk eğitimi programından yararlanmaktadır. Küba erken çocukluk gelişim ve eğitimi bütünsel bir yapıya sahip olması nedeniyle farklı kuruluş ve bireylerin ortak bir amaç doğrultusunda çalışması temeline dayanmaktadır. Bu nedenle, erken çocukluk eğitimi sadece ulusal eğitim sisteminin değil aynı zamanda ulusal sağlık sisteminin de bir parçası niteliğindedir (UNICEF, 2016).

Küba erken çocukluk eğitimi kurum merkezli programlar ve kurum merkezli olmayan programlar olarak ikiye ayrılmaktadır. Kurum merkezli olan programlar iki şekilde hizmet vermektedir. Bunlardan birincisi ebeveynleri çalışan 1-6 yaş arasındaki çocuklara hizmet etmek amacıyla kurulan günlük bakım merkezleridir. Ülke çapında 1,078 tane bulunan bu günlük bakım merkezleri Çocuk Çemberleri (Circulos infantiles- Children's circles) olarak isimlendirilmektedir. Çocuk çemberleri, Türkiye'deki kurum merkezli okul öncesi eğitim kurumlarıyla karşılaştırıldığında, bağımsız anaokullarıyla eşleştirilebilecek günlük bakım ve eğitim merkezleridir. Ebeveyni çalışan ve yürümeye başlamış çocukların başlayabileceği bu kurumlar sabah altıdan akşam yediye kadar hizmet vermektedir. Bir öğretmen ve bir yardımcı personelin birlikte çalıştığı bu kurumlarda yetişkin-çocuk oranı, 1-3 yaş aralığında bir yetişkine beş çocuk, 3-5 yaş aralığında ise bir yetişkine yedi çocuk olacak şekilde ayarlanmaktadır. $\mathrm{Bu}$ kurumlarda görev yapan personeller, üniversite veya meslek yüksekokullarından okul öncesi eğitim derecesi ile mezun olmuş öğretmenler ve okul öncesi eğitime ilişkin özel bir eğitime tabi tutulmuş ve bu eğitime devam etmesi yönünde teşvik edilen asistanlardan oluşmaktadır. Ulusal bir okul öncesi eğitim programı uygulanmasına rağmen bu program Türkiye'de uygulanan ulusal erken çocukluk eğitimi programı gibi gelişimsel kazanım ve göstergelere odaklanan (Millî Eğitim Bakanlığı[MEB], 2013), özellikle işlenecek tema veya konunun çocukların ilgi ve ihtiyaçlarına ve sosyal çevresine bağlı olarak belirlendiği bir programdır. Çocuk çemberlerinin bir diğer önemli özelliği ise çocukların sağlıklı beslenmelerine ilişkin gösterilen hassasiyetle ilgilidir. Ulusal Beslenme ve Sağlıklı Gıda Kurumu tarafından yaş grubu gelişimsel özelliklerine bağlı olarak geliştirilen bir beslenme çizelgesi takip edilir (UNESCO, 2006; UNICEF, 2016) .

Kurum merkezli olan ikinci program ise ilkokul ya da günlük bakım merkezleri bünyesinde yer alan, 5-6 yaş aralığındaki çocuklara hizmet veren ve okul öncesi sınıf (preschool grade) olarak adlandırılan kurumlardır. Bu sınıflarda görev yapan öğretmenler de bir yardımcı personelle birlikte çalışmaktadır ve bu öğretmenlerin üniversite düzeyinde okul öncesi eğitim derecesi ile mezun olmaları gerekmektedir. Bu sınıflarda ise yetişkin-çocuk oranı bir yetişkine 13 çocuk olacak şekilde ayarlanmaktadır. Ancak kurum merkezli bu okul 
öncesi eğitim kurumlarını yaygınlaştırmak ve personel sayısını arttırmak, sınırlı kaynaklar nedeniyle tam anlamıyla sağlanamamaktadır. Bu nedenle kurumsal olmayan alternatif eğitim modellerine ihtiyaç duyulmuştur (Miller, 2002; UNESCO, 2006; UNICEF, 2016).

Duyulan ihtiyaca bağlı olarak kurum merkezli programlara alternatif olarak geliştirilen, herhangi bir okul ya da binaya sahip olmayan bir program mevcuttur. Bu program 0-6 yaş çocuklara ve bu çocukların ebeveynlerine ve hamile kadınlara hizmet veren alternatif bir erken çocukluk eğitimi programıdır. Kendi Çocuğunu Eğit (Educa a Tu Hıjo- Educate Your Child) olarak çevirebileceğimiz söz konusu programdan günümüz itibariyle Kübalı çocukların yaklaşık \%70'inin faydalandığı ifade edilmektedir (Keon ve Pepin, 2008; Miller, 2002; UNESCO, 2006; UNICEF, 2016).

\section{Kendi Çocuğunu Eğit Programı}

\section{Programın Ortaya Çıkışı ve Gelişimsel Süreci}

Sosyal adalet ve eşitliği sağlamak Küba hükümeti için her zaman öncelikli bir konu olmuştur. Bu kaygıyla hareket eden Eğitim Bakanlığı 1980’lerin başında, dağlarda ve diğer kırsal kesimlerde yaşayan ve okul öncesi eğitim kurumlarına erişme şansı olmayan ailelerin çocuklarına erken çocukluk eğitimi sağlamak adına bir takım araştırmalar yürütmeye başlamıştır. Bu araştırmalar doğrultusunda Latin Amerika ülkelerinde uygulanan çeşitli erken eğitim ve müdahale programları incelenmiş ve Küba kültürü ve deneyimlerine uygun yeni bir yöntem geliştirilmiştir (Tinajero, 2010; UNICEF, 2016).

Geliştirilen bu yeni yöntem on yıl süren iki farklı aşamadan oluşan bir pilot çalışmadan elde edilen veriler ve deneyimler 1şığında güncellenmiş ve Kendi Çocuğunu Eğit Programı'na son şekli verilmiştir. Pilot çalışmanın ilk aşamasında 5-6 yaş grubuna özel olarak odaklanılmış ve ebeveynler haftada bir gün bir ilkokula davet edilerek çocuk gelişimi, okula hazır bulunuşluğu arttırma ve başarısızlığı azaltma gibi hususlarda bilinçlendirilmeye çalışılmıştır. Ancak ebeveynler 5-6 yaşından daha küçük çocuklarını da yanlarında getirmek zorunda durumunda kalmışlardır. Araştırmacıların bu süreçteki deneyimleri, çalışmalarının kapsamını 0-6 yaş aralığını içine alacak şekilde genişletmeleri gereğini ortaya çıkarmıştır (UNICEF, 2016).

1983-1987 yılları arasında gerçekleştirilen ilk pilot çalışmada 0-18 ay arasındaki 92 çocukla deneysel bir çalışma gerçekleştirilmiştir. Bu çocukların yarısı kontrol grubunda, diğer yarısı deney grubunda yer almıştır. Bu çalışmanın altında yatan temel düşünce, aileleri, kendi 
çocuklarının öğretmeni olmaları için eğitmektir. $\mathrm{Bu}$ amaçla öğretmenler, psikologlar, pediatristler, beslenme uzmanları, çocuk gelişimi uzmanları, beden eğitimi uzmanları ve sosyologlar gibi pek çok farklı alanda uzmanlıkları olan kişilerden oluşan bir ekip kurulmuştur. Bu ekip, ilk olarak çocukların hali hazırdaki gelişimini değerlendirmiş, ikinci aşamada ise ailelere ayda ya da iki ayda bir defa ev ziyaretleri gerçekleştirerek, çocukların gelişimini destekleyici etkinlikler hususunda onları bilgilendirmişlerdir. Çocukların gelişimi altı aylık dönemler şeklinde tekrar değerlendirilmiş ve araştırma verileri bu şekilde toplanmıştır. Bu araştırmanın sonunda, deney grubunda yer alan çocukların bilişsel, sosyalduygusal, fiziksel gelişim başta olmak üzere her alandaki gelişimlerinin, kontrol grubunda yer alan çocuklara göre daha iyi olduğu gözlemlenmiştir. Diğer taraftan, deney grubunda yer alan ebeveynlerin çocuk gelişimi konusundaki bilgilerinin arttığı ve ailenin çocuğun gelişiminde fark yaratmak konusunda anahtar bir role sahip olduğu sonucuna ulaşılmıştır. Ancak, sadece bu çalışmanın bulgularına dayanılarak bu program yaygınlaştııılmamış, ikinci bir pilot çalışma tasarlanarak ilk çalışmadan elde edilen bulguların geçerliliği test edilmiştir (Tinajero, 2010; UNICEF, 2016).

1987-1992 yılları arasında gerçekleştirilen ikinci pilot çalışmada örneklem genişletilerek 3852 çocuk dahil edilmiş ve kullanılan araştırma yöntemi farklılaştırılmıştır. Bu çerçevede 0-2 yaş aralığındaki çocuklar için ev ziyaretleri gerçekleştirilmiş, 3-6 yaş aralığındaki çocuklar için grup etkinlikleri düzenlenmiştir. Ancak bu aşamada aileler birincil sorumlu olma durumundan çıkarılmış ve bu sorumluluk toplum ve belirli kurumlar arasında paylaştırılmıştır. İkinci çalışmadan elde edilen bulgular bir kez daha programa dâhil olan çocuklar ve ebeveynleri lehine olumlu sonuçlar ortaya koymuş ve bir önceki çalışmanın geçerliliği test edilerek, program belediyeler düzeyinde uygulanmaya başlanmıştır (Tinajero, 2010; UNICEF, 2016).

\section{Programının Uygulama Süreci}

Temel amacı çocuğun her yönden gelişimini destekleyerek sahip olduğu potansiyeli en üst düzeyde kullanmasını sağlamak olan Kendi Çocuğunu Eğit Programı, doğum öncesi dönemden itibaren altı yaşına kadar olan çocukları kapsayan bir programdır. Çok geniş yaş aralığını kapsaması nedeniyle gruplarda yer alan ebeveyn ve çocukların ilgi ve ihtiyaçları göz önünde bulundurularak, hamile kadınlar grubu, 0-2 yaş çocuklar grubu ve 2-6 yaş arası çocuklar grubu olmak üzere 3 farklı grup oluşturulmuştur (Tinajero, 2010; UNICEF, 2016). 
Doğum öncesi dönemi kapsayan aşamada, program kapsamında ebeveynler özellikle anne adayları çocuğun sağlığını koruma ve gelişimini destekleme hususunda rehberlik alırlar. $\mathrm{Bu}$ rehberlik, haftalık veya aylık olmak üzere gerçekleştirilen ev ziyaretleri sırasında farklı sektörlerden uzmanlar tarafindan (örneğin; aile doktoru ve hemşiresi, Ulusal Spor ve Fizik Eğitimi ve Rekreasyon Enstitüsünden Uzmanlar, Sosyal hizmet uzmanları, program uygulayıcıları veya Küba Kadınları Federasyonundan üyeler) yapılır. Bu rehberliğin amacı ebeveynlere, özellikle anne adaylarına bu süreçte sağlıklarını nasıl koruyup beslenmeleri gerektiği hususunda bilgi vermek, çocuğun sağlıklı gelişimi için huzurlu ve tutarlı aile ortamının önemini vurgulamaktır (UNICEF, 2016).

Programın devamı niteliğinde olan ikinci aşamada ise 0-2 yaş aralığındaki çocuklara haftalık olarak gerçekleştirilen ev ziyaretleri aracılığıyla veya aile doktoru ofisinde gerçekleştirilen oturumlarla bireysel bakım verilir. Bu ziyaretler veya oturumlar sırasında öncelikle çocuğun gelişimi uzmanlar tarafından değerlendirilir ve programa dâhil olan en az bir aile üyesine, çocuğun gelişimini destekleyen bir uyarıcı etkinlik örnekle açıklanarak gösterilir. Söz konusu olan programın bu bölümünde çok sık olmamakla birlikte 1-2 yaş aralığındaki çocuklar için 4-6 arasında katılımcının olduğu küçük grup oturumlarının da düzenlenebildiği açıklanmaktadır (Tinajero, 2010; UNICEF, 2016).

Kendi Çocuğunu Eğit programın üçüncü grubunda yer alan 2-6 yaş arası çocukların eğitimi ise haftalık olarak gerçekleştirilen çocuğun temel bakımını üstlenen aile üyesi ile birlikte katıldığı grup etkinlikleri aracılığıyla gerçekleştirilir. Programda yer alan bu etkinlikler için çocukların 2-3, 3-4, 4-5 ve 5-6 yaş şeklinde gruplara ayrıldığı ve park, kültür merkezleri veya spor merkezleri gibi çeşitli yerlerde etkinliklerin gerçekleştirildiği açıklanmaktadır. Grubu oluşturulurken her grupta en fazla 15 çocuğun yer alabileceği şekilde bir düzenlemenin söz konusu olduğu ifade edilmektedir. Grup üyeleri ve program uygulayıcılarının bir araya geldiği buluşmalarda program uygulayıcıları tarafından çocuğun, bilişsel, sosyal, motor ya da dil gelişimini destekleyecek bir etkinliğin ailelere örneklerle açıklandığı ifade edilmektedir. Yaklaşık bir buçuk saat süren her buluşma üç aşamada gerçekleştirilir (Tinajero, 2010; UNICEF, 2016).

Programın giriş aşaması olarak nitelendirilen birinci aşamasında program uygulayıcıları tarafından ailelere bir önceki haftaya ilişkin, ailelerin etkinliği gerçekleştirip gerçekleştirmediğine, bu süreçte bir sorun yaşayıp yaşamadıklarına ve çocukların etkinlik sürecindeki tepkilerine ilişkin sorular sorulur. Bu giriş aşamasının devamında yeni etkinlik 
için gereken materyaller tanıtılarak, bu etkinliğin hangi gelişim alanlarını desteklediğine yönelik açıklamalar yapılır. Programın ikinci aşamasında ise ailelere çocuklarıyla pratik yaparak etkinliği nasıl gerçekleştirecekleri öğretilir. Bu noktada önemli olanın uygulayıcı ebeveynin etkinliği gerçekleştirme sürecini, amacına uygun bir şekilde anlamasının sağlanması olduğu ifade edilmektedir. Kapanış aşaması olarak isimlendirilen son aşamanın ise bir değerlendirme niteliğinde olduğu açıklanmaktadır. Bu süreçte çocuklarla bir uygulayıcının ilgilenmesi sağlanırken, ebeveynlerin etkinliğe ilişkin düşüncelerini açıklaması ve evde yapılacak uygulamaya yönelik sorular sorması beklenir. Bu fikir alışverişinin yanı sıra program uygulayıcıları tarafından evde yapılacak etkinliği tamamlayıcı veya geliştirici farklı etkinlikler de sunulabileceği belirtilmektedir (Tinajero, 2010; UNICEF, 2016).

Söz konusu programda özellikle 4-5 yaş grubu çocuklarının oturumlarını bir okul öncesi öğretmeninin desteklemesi planlanmıştır. Bu noktada programda amaçlananın kurumsal bir yapıda öğrenime başlayacak olan çocuklar için daha yumuşak bir geçiş, daha başarılı bir okul öncesi eğitim olduğu ifade edilmektedir. Böyle bir uygulamanın çocuk ve öğretmen etkileşiminde yaşanabilecek muhtemel uyum problemlerini en aza indirgemesi beklenmektedir. Aynı sürecin ücra yerlerde yaşadığı için kurumsal okul öncesi eğitim almayan 5-6 yaş çocuklar için de hayata geçirildiği ifade edilmektedir. Bu çerçevede, bu yaş grubunda gerçekleştirilen oturumların sıklıkla bir ilkokul birinci sınıf öğretmeni tarafından yürütüldüğü ve buradaki amacın kademeler arasındaki yumuşak geçişi ve sürekliliği sağlamak olduğu ifade edilmektedir (UNICEF, 2016).

Söz konusu program farklı yaş gruplarına yönelik olarak hazırlanmış dokuz farklı kitapçık serisinden oluşturulmuştur. Bu kitapçıkların hedeflediği yaş grubunun gelişimsel özelliklerine ve bu yaş grubunda uygulanabilecek öğretimin nasıl olması gerektiğine ilişkin bilgilerin yanı sıra, ailelere çocuklarının gelişimlerini takip edip değerlendirme olanağı sunan yaşa uygun gelişim göstergelerini de içerdiği ifade edilmektedir. Bu bilgilere ek olarak bu kitapçıklarda çocuğun sağlığının korunması ile hijyene ilişkin ve çocukla etkileşimde kibarlık, sakinlik ve saygının önemine yönelik önerilerin yer aldığı açıklanmıştır. Bu programda eğitim alan ebeveynlere söz konusu programda kullanılan kitapçıklarla birlikte okul öncesi eğitim kurumlarında kullanılmakta olan beslenme rehberi de sunulmaktadır. Ayrıca program uygulayıcıları tarafindan farklı besin grupları, yaş grubuna uygun kalori gereksinimleri gibi beslenmeye ilişkin temel bilgiler de ailelere öğretilmektedir (UNICEF, 2016). 
Programın bir diğer özelliği ise özel eğitime ihtiyaç duyan çocuklar için de uygulanabilir olmasıdır. Bu kapsamda çocuğun özel ihtiyaçları doğrultusunda rehberlik alan ailelerin kaynaştırma amacıyla grup oturumlarına dahil edilmeleri için desteklendiği belirtilmektedir (UNICEF, 2016).

\section{Kendi Çocuğunu Eğit Programında Değerlendirme Süreci}

Kendi Çocuğunu Eğit programında değerlendirme, programın temel stratejileri arasında yer almaktadır. $\mathrm{Bu}$ çerçevede, programda değerlendirme çok yönlü olarak yapıldığı açıklanmaktadır. Söz konusu programda değerlendirme sürecinin üç aşamada yapıldığı ifade edilmektedir. Bu aşamalar sırasıyla sistematik değerlendirme, çocuğun gelişiminin ve okula hazırbulunuşluğunun değerlendirilmesi ve programın tüm boyutlarıyla takip edilip değerlendirilmesi şeklinde açıklanmaktadır (Tinajero, 2010; UNICEF, 2016).

Sistematik değerlendirmenin programın uygulayıcıları tarafından aylık ev ziyaretleri sırasında gerçekleştirildiği belirtilmektedir. Gelişimsel göstergeleri içeren kontrol listeleri kullanılarak yapılan bu değerlendirmenin iki amacı olduğu açıklanmaktadır. Birincisinin çocuğun gelişimini olası gelişim sınırları içinde değerlendirmek olduğu açıklanırken, ikincisinin ise ailenin çocuğun gelişimini destekleyebilme yeterliliğini ölçmek olduğu belirtilmektedir. $\mathrm{Bu}$ değerlendirmeye ek olarak çocuk, ilkokula başlamadan önce dil, ince motor, bilişsel, sosyal-duygusal gelişim alanları açısından da çok boyutlu olarak değerlendirilmektedir. Okul öncesi ve ilkokul öğretmeninin birlikte gerçekleştirdiği bu değerlendirmenin amacının ise çocuğun gelişimsel profilini ortaya çıkarmak ve bu doğrultuda çocuğun ilkokula geçişteki sürecini desteklemek olduğu ifade edilmektedir. Daha çok çocuk boyutuna odaklanan ilk iki değerlendirmenin yanı sıra programın tüm boyutlarının ele alınıp değerlendirildiği ve Ulusal Teknik Grup tarafından birkaç yılda bir gerçekleştirilen değerlendirmeler de söz konusudur. Örneğin, 1994, 1999, 2006 ve 2014 yıllarında gerçekleştirilen değerlendirmelerde, programın, çocukların gelişimi üzerindeki ve ailelerin çocuğun gelişimini ve okula hazırbulunuşluğunu desteklemedeki yeterliliği üzerindeki etkisi değerlendirilmiştir. Ayrıca toplumun programa katılımının ve program uygulayıcılarının değerlendirilmesi de yine bu birkaç yılda bir geçekleştirilen değerlendirmelerin çalışma konuları arasında yer almaktadır (Tinajero, 2010; UNICEF, 2016).

Kendi Çocuğunu Eğit programı, hem uygulama hem değerlendirme süreci açından incelendiğinde kurumsal bir alt yapıya sahip olmamasına karşın oldukça detaylı ve çok yönlü 
olduğu görülmektedir. Gerek çocuğun farklı gelişim alanları açısından gelişimini desteklemeyi amaçlaması, gerek özel eğitime ihtiyaç duyan çocuklar açısından uygulanabilirliği ve gerekse hem uygulama hem değerlendirmeye yer vermesi yönüyle örnek gösterilebilecek bir program olduğu düşünülmektedir. $\mathrm{Bu}$ nedenle bir sonraki bölümde bu programın sahip olduğu özellikler ve yaygınlaştırma süreci ele alınarak farklı ülkelerde uygulanabilirliği tartışılmıştır.

\section{Gelişmekte Olan Ülkeler Açısından Kendi Çocuğunu Eğit Programının Değerlendirilmesi}

Kendi Çocuğunu Eğit programının elde ettiği başarı pek çok dünya ülkesi için merak konusu olmuştur. $\mathrm{Bu}$ durumu daha da ilgi çekici yapan şey ise, birçok gelişmiş dünya ülkesinin başaramadığı bir hususta Küba'nın kayda değer bir başarı elde etmesi ve tüm bunları ülkenin geçirdiği ekonomik krizin tam ortasında gerçekleştirebilmiş olmasıdır. Hamile kadınlar dâhil olmak üzere altı yaşın altındaki çocukların \%70’inin yararlandığı Kendi Çocuğunu Eğit programı, süreçte elde ettiği başarılı sonuçlardan dolayı, Ekvator, Şili, Brezilya, Meksika, Venezüella, Kolombiya ve Guatemala gibi pek çok ülkede uygulanmaya başlanmıştır. Ancak, şunu özellikle vurgulamak gerekir ki, Kendi Çocuğunu Eğit programı sadece eğitimle ilişkili kurumların planlayıp, uygulayıp ve değerlendirdiği bir program olmaktan öte birçok sektörün ve farklı gruptan insanın etkileşimli çalışarak katkıda bulunduğu özel bir program niteliği taşımaktadır (Tinajero, 2010).

Bu çalışmada Türkiye ve benzeri sosyo-ekonomik yapıya sahip ülkelerin de bu özel programın katkılarından yararlanabilmesi için programın sahip olduğu temel özellikler ayrıntılı bir şekilde açıklanarak, söz konusu programın önemine yönelik farkındalığın arttırılması hedeflenmiştir. Bu bakış açısıyla, programın bütünleştirilmiş bir sistem ile yürütülmesi, araştırma temelli politikalara dayanması, önleyici hizmetlere odaklanması ve yararlanmak isteyen herkes için erişilebilir olması gibi özelliklerinin bu bölümün devamında daha detaylı açıklanarak tartışılmasına yer verilmiştir. Ayrıca Kendi Çocuğunu Eğit programının Türkiye ve diğer gelişmekte olan ülkelerde uygulanabilirliği hususunda bir değerlendirme yapılarak bundan sonra geliştirilebilecek olan programlara düşünsel bir katkı sağlanmas1 öngörülmüștür.

\section{Bütünleştirilmiş Sistem (Sektörler arası Yaklaşım)}


Kendi Çocuğunu Eğit programının başarıya ulaşmasındaki en önemli etkenlerden biri olarak görülen sektörler arası yaklaşım uygulaması, erken çocukluk eğitiminde, sağlık ve eğitim başta olmak üzere birkaç farklı sektörün işbirliği ve koordinasyonunu gerektiren bir yap1 kurulması anlamına gelmektedir (Tinajero, 2010; UNESCO, 2006; UNICEF, 2016). Kendi Çocuğunu Eğit programı kapsamında, sağlık, beslenme, büyüme ve gelişme, kültür, spor, sosyal yardım, radyo ve televizyon kuruluşları, araştırma merkezleri ve üniversiteler, aynı amaç için işbirliği yapmaktadır. Bu kurumlardan ilgili kişiler ayda bir defa bir araya gelerek bir yıllık eylem planının uygulamasını gözden geçirerek, bölgesel uyarlama yapmakla sorumludurlar. Diğer bir deyişle, dâhil olan her sektör ve bu sektörden ilgili kişiler uzmanlık alanlarını programın uygulama boyutuna taşımaktadır. Aile doktoru ve hemşireler doğum öncesi dönemi de kapsayacak şekilde iki yaşa kadar ev ziyaretleri yaparak veya ofislerinde bakım ve gelişim konularında aileleri bilgilendirerek rehberlik etmektedir. Spor ve kültür merkezleri, müze ve spor salonu gibi mekânları grup etkinliklerine açarak programın verimli uygulanmasına katkıda bulunmaya çalışmaktadırlar. Beden eğitimi uzmanları gönüllü olarak fiziksel gelişimi destekleyici etkinlikler gerçekleştirerek programı desteklemektedirler. Diğer taraftan Küba Kadın Federasyonu, programa ailelere cinsiyet eşitliği ve cinsel eğitim gibi konularda eğitimler vererek katkıda bulunmaya çalışmaktadır. Sosyal hizmet uzmanları dezavantajlı gruplarla çalışarak önleyici bakım ve rehberlik hizmetleri sunmayı hedeflemektedir. Okul öncesi eğitim kurumları pek çok eğitim ve etkinliklerin gerçekleştirilmesine ev sahipliği yaparak katkıda bulunmaktadır. Son olarak üniversiteler, özellikle eğitim ve öğretime ilişkin bölümler, öğretim materyali geliştirme ve bilgi yönetimi hususlarında programa destek olmaya çalışmaktadır (UNICEF, 2016).

Küba'da oldukça başarılı bir şekilde uygulanmakta olan bu örnek program, aslında evrensel anlamda erken çocukluk eğitimine bakış açısının nasıl olması gerektiğini ortaya koymaktadır. Bu konuya ilişkin Türkiye ve benzeri sosyo-ekonomik yapıya sahip ülkeler için çıkarılabilecek en güzel dersin; erken çocukluk eğitimi ve gelişimini aile ve okul arasında kalan kısır bir döngü olmaktan çıkarıp, toplumun ve devletin her kesiminin bu konuya katkıda bulunabileceği bir ortak amaç haline getirmek olduğu düşünülmektedir. Ancak, bu ortak amaç haline getirme süreci, eğitimcilerin girişim ve çabalarından öte bir devlet politikası olması halinde nihai başarıya ulaşılabileceği düşünülmektedir. Çünkü bu bütünleşmiş yapı, sağlık ve eğitim personeli başta olmak üzere pek çok alandan insanın çocuk gelişimi ve eğitimi konularında eğitilmesini gerektirir. 
$\mathrm{Bu}$ eğitimin iki farklı açıdan faydasının olabileceği düşünülmektedir. Bunlardan birincisi ve en muhtemel olanı bu eğitilmiş insanların kendi uzmanlıkları çerçevesinde çocukların gelişimine katkıda bulunmasıdır. İkincisi ise toplumdaki hemen hemen her kesimden bireyin çocuk gelişimi ve eğitiminin önemi hususunda bilinçlenmesini sağlamasıdır. Böylece aileden sonra çocuk için ikinci öğrenme ortamı olan toplum, çocuk için güvenli ve destekleyici bir ortam haline gelebilir. Bu çerçeveden bakıldığında bu bütünleşik yapı pek çok amaca birden hizmet edebilir. Gelişmekte olan ülkeler için birbirinden bağımsız ve kopuk politikalar üretmek yerine kapsayıcı bir sistem geliştirmek, maliyet ve emek açısından çok daha faydalı bir sürecin oluşmasına katkıda bulunabilir.

\section{Araştırma temelli politikalar}

Var olan kaynaklarını en ekonomik ve en etkili bir biçimde kullanmayı hedefleyen Küba hükümeti, öncelikle erken eğitim alanındaki ihtiyaçlarını ve önceliklerini belirlemek amacıyla çeşitli ihtiyaç analizleri yaptırmış ve bu çalışmaların sonucuna dayanarak Kendi Çocuğunu Eğit programı için girişimler başlatmıştır. Ancak, Küba Hükümeti bu girişimlerle de sınırlı kalmayarak, on yıl süren pilot çalışmaların bulgularına dayanan politikalar geliştirmiştir (Tinajero, 2010; UNICEF, 2016). Bu yönüyle de Kendi Çocuğunu Eğit programının, eğitimin niteliğini arttırmak adına gelişmekte olan ülkelere örnek teşkil ettiği düşünülmektedir. Çünkü akademik temelli çalışmalara dayanmayan, her şeyden önce toplumun gerçek ihtiyaçlarına hitap etmeyen eğitimsel politikalar, çoğu zaman amacına ulaşmaksızın para ve emek kaybına neden olabilmektedir ve bu durum güçlü bir ekonomiye sahip olmayan gelişmekte olan ülkeleri çok daha olumsuz etkileyebilmektedir.

Kendi Çocuğunu Eğit programı gerek pilot uygulamalar gerekse yaygınlaştırma çalışmaları süresince çeşitli araştırmaların konusunu oluşturmuştur. Süreçte ortaya çıkan eksikliklerin giderilmesi ve kalitenin arttırılması amacıyla sürekli güvenilir veriye dayanan takiplerinin yapılmasının ise, programı güçlendiren ve örnek alınması gereken bir diğer yönü olduğu düşünülmektedir. Bu araştırma ve değerlendirme sonucunda yapılan değişiklik ve düzenlemelere, ailesi olmayan çocuklara odaklanma ve özel eğitime ihtiyacı olan çocuklar için özel eğitim uzmanlarını programa dâhil etme örnek olarak verilebilir (Tinajero, 2010; UNICEF, 2016). Bu durumun gelişmekte olan ülkeler ve dolayısıyla Türkiye açısından önemi ise, ülkede yapılan reform niteliğindeki düzenlemeleri yapıldığı şekliyle bırakmamak, toplumun her kesiminde nasıl algılandığını ve ne etkiler yarattığını araştırmaktır. Ancak bu 
şekilde aksayan yönlerin giderilebileceği ve yapılan reformların gerçek anlamda amacına ulaşmış sayılabileceği düşünülmektedir.

\section{Önleyici Hizmetlere Odaklanma}

Küba hükümeti, sağlık sektöründe olduğu gibi eğitim sektöründe de önleyici hizmetlere odaklanmıştır. Bu odaklanmaya bağlı olarak Kendi Çocuğunu Eğit programı kapsamında da önleyici hizmetlere önem verilmiştir. Bu önleyici hizmetler çerçevesinde, bu programa dâhil olan ebeveynlerin geçmişi, alkol veya madde bağımlılığı, gelir durumu, kronik rahatsızlı̆ olan aile bireyi gibi değişkenler açısından incelenerek çocuğun gelişimi ve eğitiminde risk oluşturacak her türlü durum önceden tespit edilmeye çalış1lmaktadır (Keon ve Pepin, 2008; UNICEF, 2016). Programın bu yönüyle de örnek oluşturduğu düşünülmektedir. Çünkü sorun ortaya çıktığı anda bu durumu çözmek için sarf edilen emek ve para, önleyici hizmetlere sarf edilen emek ve paradan daha fazla olabilmektedir. Sarf edilen emek ve paradan daha önemli olan husus ise, bireylerin gelişiminde var olan kritik gelişimsel dönemlerin atlanması halinde, bazı sorunlar bireylerin bilişsel ve fiziksel sağlı ve gelişimlerinde geri döndürülemeyecek etkiler bırakabilmektedir. Bu nedenlerden ötürü sınırlı ekonomi ve insan gücüne sahip olan ülkelerin önleyici hizmetlere odaklanması önem arz etmektedir.

\section{Herkes İçin Ücretsiz ve Ulaşılabilir Bir Eğitim}

Dağlarda ve kırsal kesimde yaşayan, okul öncesi eğitim kurumlarına ulaşma şansı olamayan çocukları eğitmek amacıyla ortaya çıkan bu program, bugün özel eğitime ihtiyacı olan çocukların programa dâhil edilmesi ve son olarak kronik hastalı̆̆ sebebiyle hastanede yaşayan ve ailelerinden dolayı hapishanede kalan çocukların programa dâhil edilmesiyle farklı bir boyut kazanmış, kapsayıcılı̆̆ı artmıştır (UNICEF, 2016). Bugün UNICEF ve UNESCO gibi pek çok uluslararası kuruluşun odak noktası dezavantajlı gruplar için eğitim olanakları sağlanmasıdır. Dolayısıyla, kurumsal olmayan alternatif erken çocukluk eğitim modellerinin önemi giderek artmaktadır. $\mathrm{Bu}$ anlamda, başarısı, ortaya çıktığı coğrafya itibariyle her yönden test edilmiş Kendi Çocuğunu Eğit programı alternatif bir model oluşturmaktadır. Bu noktada akla gelen "bu programın, ortaya çıktığı coğrafyadan sosyal ve ekonomik yap1, kültür gibi değişkenler açısından farklılık gösteren bir ülkede uygulanması mümkün müdür?” sorusunun yanıtı bir sonraki bölümde tartışılmaktadır.

\section{“Kendi Çocuğunu Eğit” Programının Uyarlanması}


$\mathrm{Bu}$ çalışmanın önceki bölümlerinde de belirtildiği gibi söz konusu program, elde ettiği başarılardan dolayı Ekvator, Brezilya Meksika, Venezüella, Kolombiya ve Guatemala gibi ülkelere uyarlanmaya çalışılmıştır. Bu uyarlama çalışmaları sırasında, Kübalı uzmanlardan, Latin Amerika Okul Öncesi Eğitim Referans Merkezi (Latin American Centre of Reference for Preschool Education) aracılığıyla eğitim ve araştırma konularında yardım alınmıştır. Ancak bu uyarlama sürecinde çeşitli direnç ve zorluklarla karşılaşılmış olduğu belirtilmiştir. Örneğin, bazı toplumlarda ebeveynler kendi çocuklarının gelişim ve öğrenmelerine katkıda bulunabilecek bir yeterliliklerinin olmadığını ifade etmişlerdir. Ancak bu gibi direnişlerin yavaş yavaş kırılabildiği belirtilse de, en büyük güçlüğün yetersiz boyutta olan politik tutarlılıktan kaynaklandığı ileri sürülmüştür (UNICEF, 2016). Burada yer verilen örneklerin de ortaya koyduğu gibi, bir eğitim programını tüm boyutları ile aynen alıp uygulamanın kültürel ve siyasi yapıdan kaynaklanan farklılıklardan ötürü çeşitli sorunlarla karşılaşılmasına neden olabileceği düşünülmektedir. Ancak, bir önceki bölümde de sıklıkla vurgulandığı gibi örnek oluşturan bu gibi uygulamaların katkılarından yararlanmanın ve kendi koşullarımızda en etkili sonuçlar verebilecek yönleri itibari ile uygulamaya taşımanın önem arz ettiği düşünülmektedir.

\section{Sonuç}

Sonuç olarak, bu çalışmada da sıklıkla vurgulandığı gibi erken çocukluk döneminde çocuğa kendi potansiyel gelişimini en üst düzeye çıkarabileceği eğitimsel uygulamalar sunulmasının önemi giderek artmaktadır. Bu nedenle, günümüzde pek çok araştırmacı ve eğitimci çocuğun ilgi ve ihtiyaçlarına hitap edebilecek alternatif eğitim yöntem ve stratejileri arayışı içerisindedir. Bu çerçeveden bakıldığında, Küba erken çocukluk eğitim modelinin ve daha özelinde Kendi Çocuğunu Eğit programının eğitimde alternatif yöntem ve strateji arayan ve bunları kendi eğitim ortamına taşımak isteyen araştırmacı ve öğretmenler açısından önemli bir model oluşturduğu düşünülmektedir. Bu taşıma işlemini bir adım daha kolaylaştırmak amacıyla yapılan bu çalışmada, Kendi Çocuğunu Eğit programı tanıtılarak ve kültürel uyarlamaların önemine değinilmiştir. 
Ege Eğitim Dergisi 2017 (18) 1: 56-82

Erken Çocukluk Eğitimine Küba Perspektifinden Alternatif Bir Bakış: Kendi Çocuğunu Eğit Programı 


\section{Kaynakça}

Birleşmiş Milletler, BM. (2015). Human development report 2015: Work for human development. $\quad \underline{\text { http://hdr.undp.org/sites/default/files/hdr_2015_statistical_annex.pdf. }}$ adresinden elde edildi.

Barredo, A. (2013). Education for children with special needs in Cuba: Equality, justice and social commitment. The Havana Reporter, 11.

Breidlid, A. (2007). Education in Cuba-an alternative educational discourse: Lessons to be learned? A Journal of Comparative and International Education, 7(5), 617-634.

British Broadcasting Corporation, BBC. (2014). BBC News: Latin America \& Caribbean: Cuba profile. http://www.bbc.com/news/world-latin-america-19583447. adresinden elde edildi.

Centre on the Developing Child. (2010). The foundations of lifelong health are built in early childhood. http://developingchild.harvard.edu/wpcontent/uploads/2010/05/Foundations-of-Lifelong-Health.pdf. adresinden elde edildi.

Dünya Bankası (2014). The World Bank working for a world free of poverty: Data. http://data.worldbank.org/indicator. adresinden elde edildi.

Everett, N. (2012, February-April). Education for liberation: behind Cuba's education success. Direct Action for Socialism in the 21st Century, 38. http://directaction.org.au/issue38/education_for_liberation_behind_cuba_s_education_ success. adresinden elde edildi.

Fisher, M. A. (2011). The early years and brain development: The critical connections of building relationships. Gail L. Ensher ve David A. Clark (Ed.) Relationship-centered practices in early childhood: Working with families, infants, and young children at risk içinde (s. 33-44). Baltimore, MD, US: Paul H Brookes Publishing.

Fry, R. (2002). Latinos in higher education: Many enroll, too few graduate. http://files.eric.ed.gov/fulltext/ED468848.pdf. adresinden elde edildi.

Gasperini, L. (2000). The Cuban education system: Lessons and dilemmas. Country Studies Education Reform and Management Publication Series, 1(5), 1-33. 
Güven, G. ve Efe Azkesin, K. (2014). Erken Çocukluk Eğitimi ve Okul Öncesi Eğitim. İbrahim H. Diken (Ed.), Erken Çocuklukluk Eğitimi içinde (s. 2-50). Ankara: Pegem Akademi

Gorry, C. (2010). Protecting children takes more will than resources: Interview with José Juan Ortiz, UNICEF representative in Cuba. MEDICC Review, 12(2), 10-12. http://medicc.org/mediccreview/articles/mr_139.pdf. adresinden elde edildi.

Haartsen, R., Jones, E. H., ve Johnson, M. H. (2016). Human brain development over the early years. Current Opinion In Behavioral Sciences, 10, 149-154. doi: 10.1016/j.cobeha.2016.05.015

Hoi, KaLeng Crystal. (2010). Learning from Cuba's model: Recommendations on early childhood education and care programs in British Columbia. (Yayımlanmamış yüksek lisans tezi). Simon Fraser University, British Columbia.

Keon, W. J. ve Pepin, L. (2008, February). Maternal health and early childhood development in Cuba. http://www.parl.gc.ca/Content/SEN/Committee/392/soci/rep/rep08feb08e.pdf. adresinden elde edildi.

Lopez, M. Q. (2011). Education in Cuba: Foundations and challenges. Estudos Avançados, 25(72), 55-71. http://www.scielo.br/pdf/ea/v25n72/en_a06v25n72.pdf adresinden elde edildi.

Mandrapa, N. (2005). Education system of Cuba - Path to success. https://novakdjokovicfoundation.org/education-system-of-cuba-path-to-success/. adresinden elde edildi.

McCloskey, S. (2011). Cuba’s model of development: Lessons for global education. Policy \& Practice: A Development Education Review, 13, 84-98.

Milli Eğitim Bakanlığı (MEB). (2013). Okul öncesi eğitim programı. http://ttkb.meb.gov.tr/www/ogretim-programlari/icerik/72. adresinden elde edildi.

Miller, S. A. (2002). Early childhood education in Cuba. Childhood Education, 78(6), 359362. 
NAEYC. (2000). A call for excellence in early childhood education. http://www.naeyc.org/policy/excellence. adresinden elde edildi.

Nagel, M. C. (2012). In the beginning: The brain, early development and learning. ACER Press.
OECD
(2010).
PISA
2009
Results:
Executive
summary.

http://www.oecd.org/pisa/pisaproducts/46619703.pdf. adresinden elde edildi.
OECD
(2012).
PISA
technical
report.

http://www.oecd.org/pisa/pisaproducts/pisa2009/50036771.pdf. adresinden elde edildi.

OECD, (2015). Education at glance: OECD indicators, OECD publishing. http://www.oecdilibrary.org/docserver/download/9615031e.pdf?expires=1474977311\&id=id\&accname= guest\&checksum=3578C2EFAAAF2B58269DEC4583117096. adresinden elde edildi.

Tinajero, A. (2010). Scaling-up early child development in Cuba-Cuba's educate your child program: Strategies and lessons from the expansion process. Washington, DC: The Brookings Institution.

United Nations Educational, Scientific and Cultural Organization, UNESCO. (2006). Cuba early childhood care and education (ECEC) programmes. http://unesdoc.unesco.org/images/0014/001480/148Q99e.pdf. adresinden elde edildi.

UNESCO (2013). Country Profile. http://uis.unesco.org/country/CU. adresinden elde edildi.

UNICEF. (2013). UNICEF Cuba statistics. http://www.unicef.org/infobvcountrv/cuba statistics.html. adresinden elde edildi.

UNICEF. (2016). Early childhood development in Cuba: Sharing the experience of a scaledup integrated system that promotes the best start in life for every child. http://www.unicef.org/cuba/cu_resources_earlychildhooddevelopmentlibro.pdf. adresinden elde edildi.

Wardle, F. (2009). Approaches to early childhood and elementary education. New York: Nova Science Publishers. 
Wolf, S., Penton, F. A. H., Marin, A. L. B., Romero, O. (2011). The Cuban vocational education and training system and its current changes. Journal for Critical Educational Policy Studies, 9(1), 223-240.

Velkovski, Z. ve Misik, E. (2011). Lessons for scaling up Cuba's educate your child programme. Early Childhood Matters, 117, 6-11.

Yoshikawa, H., Weiland, C., Brooks-Gunn, J., Burchinal, M.R., Espinosa, L.M., Gormley, W.T., ve Zaslow, M.J. (2013). Investing in our future: The evidence base on preschool education. society for research in child development and foundation for child development. http://fcd-us.org/resources/evidence-base-preschool. adresinden elde edildi. 


\section{Extended Abstract}

The purpose of this study is to introduce the Cuban early childhood education system, particularly the Educate Your Child programme. The study also aims to discuss the applicability of this programme in Turkey and in other developing countries. To this end, related literature and reports by UNICEF and UNESCO about Cuban early childhood education are examined in detail. Depending on the related literature, the researchers first introduce Cuba by presenting its social, economic, and political structure. From this point of view, the development model of Cuba is presented in order to enable the readers to gain insight about Cuba and to evaluate the reforms in early childhood education by considering its own conditions. Thus, basic details about Cuba are briefly presented.

Cuba, a Caribbean island between the Caribbean Sea and the North Atlantic Ocean, is located south of Florida. The country is formally called the Republic of Cuba, but the political regime is communist. The Cuban economy experienced an economic blockade imposed by the United States beginning in 1961, and during much of this time, the Union of Soviet Socialist Republics (USSR) provided financial aid to the country. However, this aid was removed with the collapse of the USSR, and Cuba therefore adopted economic liberalization to deal with the economic issues (BBC, 2014).

Following the revolution, Cuba began to apply some essential changes to improve the quality of social life. To achieve this goal, the government especially focused on the education and health sectors, which constituted the basis of Cuba's development model. Prominent components of this model include the one-year literacy campaign, the establishment of a national health system, the free access of Cuban citizens to education and health services, the offer of nonformal education programs, and the integration of the education and health sectors. This development model made Cuba attractive for researchers from the education and health fields. For instance, the success of the Cuban education system is on the agenda of many studies in the field of education (e.g., Hoi, 2010; Everett, 2012; Tinajero, 2010).

The Cuban government has best succeeded in many aspects of education such as the literacy campaign (McCloskey, 2011), special education (Gasperini, 2000), high enrolment in higher education (Fry, 2002), and teacher education standards (Gasperini, 2000). However, this study focuses on early childhood education in Cuba and particularly on the Educate Your 
Child programme. Therefore, having briefly touched on the country's general education system, this study secondly introduces the early childhood education system of Cuba. Early childhood education has been a focus point of the Cuban government and the Ministry of Education in order to increase the quality of education. Hence, important initiatives such as the Educate Your Child programme have been a feature of early childhood education since the revolution (Tinajero, 2010). Cuban early childhood education is not compulsory, but it is free for children from birth to their entry into primary school (i.e., for children aged up to six years old). Both institutional and noninstitutional channels are used to organize early childhood education in Cuba. Child care programs come in three types, including children's circles (6 months to 5 years of age), the Educate Your Child programme (0-6 years old), and the preschool grade (for 5 year olds) (Keon ve Pepin, 2008).

The Educate Your Child programme is a community-based programme which started in 1983 with the support of the Ministry of Education and UNICEF. The main purpose of this programme is to achieve children's whole development and learning. To achieve this, promoters (e.g. teachers and health workers) and facilitators (e.g. families and community members) work in collaboration. Their mission is to educate the community, mobilize educational resources and materials, and train facilitators who guide the children's education as well (Velkovski ve Misik, 2011). The programme includes two age groups, 0-2 and 2-6 year-olds. The type of educational programme changes depending on the age group. For example, individualized care and home visits take place with the first age group (0-2 years old), whereas children between the ages of 2 and 6 participate in group sessions with parents and educators in community spaces such as parks and museums (Tinajero, 2010; UNICEF, 2016).

One of the main aims of this study is to discuss lessons for Turkey and developing countries in reference to the noteworthy aspects of this programme in Cuba. From this perspective, lessons offered by the Educate Your Child programme, for Turkey and for other developing countries, may include the integration of health and education, participation by all sectors of society, early intervention and prevention, and ongoing development mentoring. 